\title{
Technological Progress, Structural Change and Productivity Growth; A comment
}

Citation for published version (APA):

Carree, M. A. (2003). Technological Progress, Structural Change and Productivity Growth; A comment. Structural Change and Economic Dynamics, 14, 109-115. https://doi.org/10.1016/S0954-349X(02)000358

Document status and date:

Published: 01/01/2003

DOI:

10.1016/S0954-349X(02)00035-8

Document Version:

Publisher's PDF, also known as Version of record

\section{Please check the document version of this publication:}

- A submitted manuscript is the version of the article upon submission and before peer-review. There can be important differences between the submitted version and the official published version of record.

People interested in the research are advised to contact the author for the final version of the publication, or visit the DOI to the publisher's website.

- The final author version and the galley proof are versions of the publication after peer review.

- The final published version features the final layout of the paper including the volume, issue and page numbers.

Link to publication

\footnotetext{
General rights rights.

- You may freely distribute the URL identifying the publication in the public portal. please follow below link for the End User Agreement:

www.umlib.nl/taverne-license

Take down policy

If you believe that this document breaches copyright please contact us at:

repository@maastrichtuniversity.nl

providing details and we will investigate your claim.
}

Copyright and moral rights for the publications made accessible in the public portal are retained by the authors and/or other copyright owners and it is a condition of accessing publications that users recognise and abide by the legal requirements associated with these

- Users may download and print one copy of any publication from the public portal for the purpose of private study or research.

- You may not further distribute the material or use it for any profit-making activity or commercial gain

If the publication is distributed under the terms of Article $25 \mathrm{fa}$ of the Dutch Copyright Act, indicated by the "Taverne" license above, 


\title{
Technological progress, structural change and productivity growth: a comment
}

\author{
M.A. Carree ${ }^{a, b, *}$ \\ a Erasmus University Rotterdam, P.O. Box 1738, 3000 DR Rotterdam, The Netherlands \\ b Maastricht University, PO Box 616, 6200 MD Maastricht, The Netherlands
}

Received 2 April 2001; received in revised form 11 March 2002; accepted 26 July 2002

\begin{abstract}
In a recent article, Fagerberg [Struct. Change Econ. Dyn. 11 (2000) 393] finds changes in the employment share of the electrical machinery industry to positively impact the manufacturing sector productivity growth. Fagerberg's approach has some methodological drawbacks, however. This note seeks to complement Fagerberg's analysis by estimating the impact of the employment share of technologically progressive industries using a more adequate methodology. Fagerberg's claim that the share of the 'electronics' industry positively affects manufacturing is confirmed. However, the size of the impact, and as a consequence the extent of spill-overs, is found to be much smaller than estimated by Fagerberg.

(C) 2002 Elsevier Science B.V. All rights reserved.
\end{abstract}

JEL classification: $\mathrm{O} 14 ; \mathrm{O} 33$

Keywords: Technological progress; Structural change; Productivity growth

\section{Introduction}

In a recent article, Fagerberg (2000) focuses on the relationship between the economic structure of a country and its productivity growth. He argues that the 'electronics revolution' will have impacted labour productivity in the manufacturing

* Present address: MW-ORG, Faculty of Economics and Business Administration, Maastricht University, P.O. Box 616, 6200 MD Maastricht, The Netherlands. Tel.: +31-43-3883763; fax: +31-43388-4877

E-mail address: m.carree@mw.unimaas.nl (M.A. Carree). 
sector through important spill-over effects. This argument is given empirical backing by estimation results of an increase in the share of the electrical machinery industry (ISIC 383) in total manufacturing to have a positive and significant effect on the growth of total manufacturing productivity in the same period. Fagerberg uses a sample of 37 countries for the 1973-1990 period and finds that a $1 \%$ increase in the share of employment working in the electrical machinery industry has a predicted $0.5 \%$ higher growth of total manufacturing productivity. He shows that the size of this impact is very stable across different specifications. These results would suggest very strong spill-over effects of the 'electronics revolution'.

In the present note I will show that the specification and sample used by Fagerberg are likely to give biased results. I propose a more accurate procedure and use the OECD STAN Database providing data on the high-technology industries at a lower level of aggregation to obtain more reliable estimates. My results confirm Fagerberg's finding that the share of the 'electronics' industry has a positive and significant impact on total manufacturing productivity. The estimated size of the impact is much more modest though. I find a $1 \%$ increase in the employment share of the electrical machinery industry to have a $0.2 \%$ higher subsequent growth of total manufacturing productivity. That is, the extent of spill-over effects is estimated to be much lower than in Fagerberg's results.

\section{Fagerberg's specification and sample}

Fagerberg uses the following type of specification to estimate the impact of the share of an industry in a country $i\left(x_{i}\right)$ on labour productivity $\left(y_{i}\right.$ being the logarithm of value added over employment)

$$
y_{i t}-y_{i, t-L}=\alpha+\beta y_{i, t-L}+\gamma\left(x_{i t}-x_{i, t-L}\right)+\varepsilon_{i t} \quad i=1, \ldots, N
$$

where $N$ is the number of countries and $L$ is the length of the period under consideration. The sample that Fagerberg uses has $N$ equal to 37 and $L$ equal to 17 years. There are two important potential problems with this specification. First, the growth in labour productivity is measured in the same period as the change in the industry share. This may adversely affect the possibility of testing of (Granger) causality. The reason is that it is impossible to statistically discriminate between a situation in which the change in the industry share or productivity change takes place largely in the first part of the period or the second part of the period. Therefore, it is possible that most of the productivity growth of a country precedes the growth in the industry employment share. The length of the period of 17 years over which the changes are computed implies that there can be a lot of intra-period variation.

Second, the industry share at the start of the period $\left(x_{i, t-L}\right)$ is not incorporated in Eq. (1). As a consequence, countries with equal changes in the industry employment share but vastly different levels of this share are not distinguishable. Fagerberg pays attention to this issue on p. 406 (footnote 12) but does not provide empirical results 
when incorporating the initial industry share in the equation. Fagerberg's argument that the initial industry share is not very relevant because the electrical machinery industry of the early 1970s is very different from that of the early 1990s, is not entirely convincing. Even in case the 'electronics' industry employment share remains constant over time, there may have been a lot of firm entry and exit and innovation in products and processes in that industry. For example, Portugal and the US both show an increase of about $1 \%$ point in the electrical machinery industry employment share over the period under consideration. However, the initial employment share in the early 1970s in the US was more than double that of Portugal. An investigation of the relationship between structure and productivity growth should not disregard such differences.

In addition to these two problems concerning Eq. (1) there is one key disadvantage to the choice of the data set. The electronics industry in the data set used by Fagerberg is partly in one 3-digit industry and partly in another (ISIC 382 and 383) with also other activities being incorporated in each of those two industries. This disadvantage is expressed by Fagerberg on p.396 (footnote 5). If we take the R\&D over output ratio as a criterion of technological progressiveness the high-tech and less high-tech parts of the industries can be ranked in order of progressiveness as follows (source: Martins et al. (1996), p. 23): Radio, TV and communication equipment (ISIC 3832), Office and computing machinery (ISIC 3825), Electrical machinery except 3832 (ISIC 383X) and Non-electrical machinery except 3825 ( $382 \mathrm{X})$. The last of the four even cannot be considered to be among the top R\&D intensive industries. In order to arrive at a more definitive appraisal of the role that technologically progressive industries play an analysis at a more disaggregated level than used by Fagerberg appears necessary. Martins et al. (1996), p. 23 provide the following top five of industries with regard to R\&D intensity: Drugs and medicines (ISIC 3522), Aircraft (ISIC 3845), Radio, TV and communication equipment (ISIC 3832), Office and computing machinery (ISIC 3825) and Professional goods (ISIC 385). I investigate the impact of the industry employment share of each of these industries except for Aircraft which is present as an important industry only in a handful of countries.

The current note will use the OECD STAN Database to investigate the effect of the share of the electronics and other high-tech industries. It implies that only OECD countries are incorporated. Fagerberg incorporates a substantial group of Less Developed Countries (LDCs) in his sample. This has the advantage of increasing the sample size. A potential disadvantage, though, is that the products and performance of the electronics industries in countries like Iran, Algeria, Colombia and Sri Lanka may not be comparable to those of the more developed countries. Quite a few LDCs have had their economies (and manufacturing productivities) suffer from political and monetary instabilities during the 1970s and 1980s. In case these same countries have been slow in expanding their technologically progressive industries the results presented by Fagerberg may be biased. In this study I will focus on OECD countries and limit this potential bias. 


\section{Alternative specification and the OECD STAN database}

Instead of using specification Eq. (1), I will use the following specification:

$$
\begin{aligned}
& y_{i t}-y_{i, t-M}=\alpha_{t}+\beta y_{i, t-M}+\gamma\left(x_{i t}-x_{i, t-M}\right)+\delta x_{i, t-M}+\varepsilon_{i t} \quad i=1, \ldots, N \\
& t=1, \ldots, L / M
\end{aligned}
$$

where $M<L$. There are two differences between specifications Eq. (1) and Eq. (2). First, the period under investigation is divided into sub-periods. This makes the period during which the initial industry employment share and the change in this share affect productivity growth shorter. In fact, I will use data for the 1972-1992 period $(L=20)$ and divide it into four sub-periods $(M=5)$, viz. 1972-1977, 1977 1982, 1982-1987 and 1987-1992. A choice for shorter time periods instead of a long time-span leads, on the one hand, to a more appropriate measurement of the effect of economic structure, but may, on the other hand, increase sensitivity to business cycles. Second, the initial industry employment share is added as an extra explanatory variable.

The data used for estimating Eq. (2) are from the OECD STAN Database 19701995 (OECD, 1997). I use data for the following 20 OECD countries: Australia, Austria, Canada, Denmark, Finland, France, Germany, Greece, Italy, Japan, Korea, Mexico, The Netherlands, New Zealand, Norway, Portugal, Spain, Sweden, UK and US. All of these countries were also incorporated by Fagerberg with the exception of Mexico. I focus on five technologically advanced industries, viz. Pharmaceuticals (ISIC 3522), Office and computing machinery (ISIC 3825), Radio, TV and communication equipment (ISIC 3832), Electrical machinery except 3832 (ISIC 383X) and Professional Goods (ISIC 385). The Radio, TV and communication equipment industry is the most important from the perspective of what is most representative of 'electronics'. As a measure of the labour productivity I use the logarithm of total manufacturing value added in thousand US dollars divided by total manufacturing employment. The number of observations was less than the possible 80 (20 countries times four periods) because for some countries or periods employment share data were not available depending upon which industries were taken into consideration. Summary statistics of the change in the industry employment shares and their initial levels are given in Table 1. The data on the industry shares show that the Pharmaceuticals (ISIC 3522) and Office and computing machinery (ISIC 3825) industries are quite small in terms of employment share. The Radio, TV and communication equipment (ISIC 3832) and the other part of the ISIC 383 sector are much larger, with shares of around $4 \%$ on average. The total sum of the shares of the five industries is about $10 \%$ on average.

\section{Empirical results}

The empirical results are presented in Table 2. Results are shown also in the case of omitting the change in the industry employment share as independent variable 
Table 1

Summary statistics of the change in industry shares and their initial levels

\begin{tabular}{lrrr}
\hline Variable & ISIC & Mean & S.D. \\
\hline$\Delta_{5} x_{i t}$ & 3522 & 0.0010 & 0.0015 \\
$\Delta_{5} x_{i t}$ & 3825 & 0.0009 & 0.0027 \\
$\Delta_{5} x_{i t}$ & 3832 & 0.0014 & 0.0086 \\
$\Delta_{5} x_{i t}$ & $383 \mathrm{X}$ & -0.0001 & 0.0048 \\
$\Delta_{5} x_{i t}$ & 385 & 0.0016 & 0.0025 \\
$x_{i, t-5}$ & 3522 & 0.0106 & 0.0039 \\
$x_{i, t-5}$ & 3825 & 0.0070 & 0.0058 \\
$x_{i, t-5}$ & 3832 & 0.0402 & 0.0283 \\
$x_{i, t-5}$ & $383 \mathrm{X}$ & 0.0418 & 0.0145 \\
$x_{i, t-5}$ & 385 & 0.0147 & 0.0120
\end{tabular}

The number of observations for the change in the industry employment shares is 66 . The number of observations for the initial shares is 67 .

(hence $\gamma=0$ ) to avoid possible endogeneity. The empirical results presented in column (i) show that there is no significant impact on productivity growth of the 5year change in the industry employment share of any of the five industries. Also, when the five $\Delta_{5} x_{i t}$-variables are left out, the $R$-squared barely diminishes. The results on the effect of the initial employment shares of the industries show that only one industry did in fact positively and significantly impact the productivity growth, viz. the Radio, TV and communication equipment industry (ISIC 3832), precisely the one which is most technologically progressive and is most representative of 'electronics'. The results presented in the columns (v) and (vi) of the table show that the coefficient of the impact of this industry is not very different from that of the rest of the ISIC 383 sector, but the coefficient is more precisely estimated. The size of the coefficient suggests that a $1 \%$ higher share of the electronics industry has almost a $1 \%$ higher productivity growth over a 5 year period, or approximately $0.2 \%$ per annum. This is much lower than the estimate presented by Fagerberg, which was about $0.5 \%$. However, it should be noted that Fagerberg found a significant effect of the (long-term) changes in employment share instead of the level of employment share. A direct comparison of the results is further complicated by the difference in the sample of countries. Nevertheless, the result that a (increased) presence of the 'electronics' industry positively affects total manufacturing productivity growth, while other technologically progressive industries fail to do so, is left confirmed. Therefore, Fagerberg's claims of substantial benefits having been received by countries that changed their economic structure towards the electronics industry remain to receive empirical support even using a strongly different set-up. The extent of these benefits appears more modest, though.

The only control variable included in model (Eq. (2)) is the initial level of productivity. In addition to this, Fagerberg also incorporated investment and primary and secondary education variables. The latter are less relevant for the current paper because it has a sample of more developed countries. However, the incorporation of a control for the rate of investment has been considered. It would 
Table 2

The effect of (changes in) structure on productivity growth

\begin{tabular}{|c|c|c|c|c|c|c|c|c|}
\hline Variable & Parameter & ISIC & (i) & (ii) & (iii) & (iv) & (v) & (vi) \\
\hline$y_{i, t-5}$ & $\beta$ & & $\begin{array}{l}-0.149 * \\
(2.7)\end{array}$ & $\begin{array}{l}0.120 \\
(1.8)\end{array}$ & $\begin{array}{l}-0.153^{*} \\
(3.1)\end{array}$ & $\begin{array}{l}-0.119^{*} \\
(2.1)\end{array}$ & $\begin{array}{l}-0.140^{*} \\
(3.4)\end{array}$ & $\begin{array}{l}-0.146^{*} \\
(3.8)\end{array}$ \\
\hline$\Delta_{5} x_{i t}$ & $\gamma$ & 3522 & $\begin{array}{l}1.810 \\
(0.2)\end{array}$ & $\begin{array}{l}6.112 \\
(0.7)\end{array}$ & & & & \\
\hline$\Delta_{5} x_{i t}$ & $\gamma$ & 3825 & $\begin{array}{l}-0.041 \\
(0.0)\end{array}$ & $\begin{array}{l}-1.379 \\
(0.3)\end{array}$ & & & & \\
\hline$\Delta_{5} x_{i t}$ & $\gamma$ & 3832 & $\begin{array}{l}-0.471 \\
(0.3)\end{array}$ & $\begin{array}{l}0.139 \\
(0.1)\end{array}$ & & & $\begin{array}{l}-0.562 \\
(0.5)\end{array}$ & \\
\hline$\Delta_{5} x_{i t}$ & $\gamma$ & $383 X$ & $\begin{array}{l}1.477 \\
(0.6)\end{array}$ & $\begin{array}{l}1.204 \\
(0.5)\end{array}$ & & & $\begin{array}{l}1.000 \\
(0.5)\end{array}$ & \\
\hline$\Delta_{5} x_{i t}$ & $\gamma$ & 385 & $\begin{array}{l}-4.078 \\
(1.0)\end{array}$ & $\begin{array}{l}-6.772 \\
(1.3)\end{array}$ & & & & \\
\hline$x_{i, t-5}$ & $\delta$ & 3522 & $\begin{array}{l}-4.034 \\
(1.4)\end{array}$ & $\begin{array}{l}-4.978 \\
(1.5)\end{array}$ & $\begin{array}{l}-4.214 \\
(1.6)\end{array}$ & $\begin{array}{l}-4.833 \\
(1.7)\end{array}$ & & \\
\hline$x_{i, t-5}$ & $\delta$ & 3825 & $\begin{array}{l}-2.091 \\
(0.7)\end{array}$ & $\begin{array}{l}-2.629 \\
(0.9)\end{array}$ & $\begin{array}{l}-1.879 \\
(0.8)\end{array}$ & $\begin{array}{l}-2.260 \\
(0.9)\end{array}$ & & \\
\hline$x_{i, t-5}$ & $\delta$ & 3832 & $\begin{array}{l}0.934^{*} \\
(2.2)\end{array}$ & $\begin{array}{l}0.909 * \\
(2.1)\end{array}$ & $\begin{array}{l}1.021^{*} \\
(2.9)\end{array}$ & $\begin{array}{l}0.949 * \\
(2.6)\end{array}$ & $\begin{array}{l}0.850^{*} \\
(2.5)\end{array}$ & $\begin{array}{l}0.895^{*} \\
(2.8)\end{array}$ \\
\hline$x_{i, t-5}$ & $\delta$ & $383 X$ & $\begin{array}{l}0.786 \\
(0.9)\end{array}$ & $\begin{array}{l}0.874 \\
(0.9)\end{array}$ & $\begin{array}{l}0.787 \\
(1.0)\end{array}$ & $\begin{array}{l}0.985 \\
(1.2)\end{array}$ & $\begin{array}{l}0.674 \\
(1.2)\end{array}$ & $\begin{array}{l}0.729 \\
(1.4)\end{array}$ \\
\hline$x_{i, t-5}$ & $\delta$ & 385 & $\begin{array}{l}1.056 \\
(0.9)\end{array}$ & $\begin{array}{l}1.268 \\
(1.1)\end{array}$ & $\begin{array}{l}0.901 \\
(0.8)\end{array}$ & $\begin{array}{l}1.096 \\
(1.0)\end{array}$ & & \\
\hline $\mathrm{INV}_{i, t-5}$ & & & & $\begin{array}{l}0.149 \\
(0.6)\end{array}$ & & $\begin{array}{l}0.225 \\
(1.0)\end{array}$ & & \\
\hline$R^{2}$ & & & 0.639 & 0.659 & 0.636 & 0.646 & 0.614 & 0.612 \\
\hline Observations & & & 66 & 62 & 67 & 63 & 75 & 75 \\
\hline
\end{tabular}

The dependent variable is the chance in the logarithm of value added per employee in thousand US dollars over a 5 -year period, or $y_{i t}-y_{i, t-5}$. Time dummies included. $T$-values between brackets. In columns (ii) and (iv) the initial ratio of gross fixed capital formation to value added in total manufacturing (INV) is incorporated as a control variable. This variable was unavailable for Mexico. The 5 observations not included in the last two columns are Australia and New Zealand 1987-92, Germany and Spain 197277 and Spain 1977-82.

* Significance at the 5\%-significance level.

seem likely that manufacturing sectors with relatively high rates of investment generate stronger labour productivity growth than their counterparts with relatively low investment rates. As a measure of the investment rate the ratio of gross fixed capital formation to total value added for the manufacturing sector (INV) is chosen (source: OECD, 1997). Columns (ii) and (iv) of Table 2 show the results when this control variable is incorporated. In both cases a positive but insignificant effect is found. Furthermore, the impact on the other estimation results is limited.

An interesting potential control variable, not incorporated by Fagerberg, is R\&D intensity (a referee pointed this out). There are two complications with regard to a R\&D-intensity variable. First, they are available only for a smaller set of countries. For example, the OECD ANBERD database does not contain data for 6 of the 20 
countries in the sample (Austria, Greece, Korea, Mexico, New Zealand and Portugal). Incorporating a variable based upon these R\&D-data into the model would not only reduce the number of observations, but also leave the sample consisting of only highly developed economies. In fact, when estimating the model (Eq. (2)) for the sample of 47 observations for which also ANBERD data is available, the effect of the share of the 'electronics' industry (ISIC 3832) was still positive but not significant, even when a $R \& D$ control variable was not incorporated. Second, a R\&D control variable will be strongly correlated with the share of the technologically progressive industries. It is precisely through increased R\&D that a higher share of these industries may affect economic performance (next to other spill-over effects). $R \& D$ is not an independently determined control variable in the model. An extended model, outside the scope of this comment, would be needed to take the interdependencies into account.

\section{Acknowledgements}

The author is grateful for financial support by the Royal Netherlands Academy of Arts and Sciences (KNAW). Referee comments have been helpful in achieving the present version of this comment. Technological progress, structural change and productivity growth: a comment.

\section{References}

Fagerberg, J., 2000. Technological progress, structural change and productivity growth: a comparative study. Structural Change and Economic Dynamics 11, 393-411.

Martins, J.O., Scarpetta, S., Pilat, D., 1996. Mark-up ratios in manufacturing industries: Estimates for 14 OECD countries, OECD Economics Department Working Papers no. 162, OECD, Paris.

OECD, 1997. The OECD STAN Database 1970-1995, Economic Analysis and Statistics Division, Paris. 